\title{
A REVIEW OF HATCHERY TECHNIQUES OF RED TILAPIA (Oreochromis niloticus) AT UPT OF FRESHWATER AQUACULTURE FISHERIES (PBAT), PASURUAN
}

\author{
Ashil Falih Kes Foh Al Ghozali ${ }^{1}$, Asri Sawiji ${ }^{1}$, Doddy Gunawan ${ }^{2}$ \\ ${ }^{1)}$ Marine Science Department, UIN Sunan Ampel Surabaya \\ ${ }^{2)}$ UPT PBAT of Pasuruan \\ E-mail : ashilkesfoh@gmail.com
}

\begin{abstract}
The UPT of Freshwater Aquaculture Fisheries (PBAT) of Pasuruan is one of the superior seed supply units for fisheries in East Java. The superior commodity is tilapia fish seeds. Red tilapia (Oreochromis niloticus) has its advantages compared to other cultivated fish. Namely, it can proliferate, is easy to breed, and is efficient for feeding. Besides, these fish can also tolerate changes in the aquatic environment. With these advantages, this fish is increasingly popular among cultivators. The need for tilapia fish seeds is increasing every year. This review provides hatchery techniques for red tilapia (Oreochromis niloticus) at UPT PBAT Pasuruan, based on field survey. The review includes information relating to media preparation, parent selection, spawning, larvae harvest and treatment, nursery, harvest of seeds, and also water quality control, and pest and disease control.
\end{abstract}

Keywords: Red tilapia culture, hatchery quality, UPT PBAT

\section{INTRODUCTION}

One type of freshwater fish that has great potential for cultivation is red tilapia (Oreochromis niloticus). Tilapia began to develop in Indonesia in 1981. Its development aimed to enrich the types of cultivated fish. Due to the fast maintenance of tilapia in time, which is only six months, it has reached a 300-500gr / fish consumption size. In 1986 red tilapia was the most popular cultivated fish after goldfish [1].

According to [2], tilapia's morphology, namely the body width of tilapia, is generally one-third of its body length. The body shape is elongated and slender; the tilapia scales are relatively large; the eyes are prominent and large with white edges. The male parent's characteristics are visible in having a genital hole in a slightly tapered protrusion that functions as a sperm channel and urinary tract. On the front, there is an anus. The female parent has three channels: anus, a hole for removing eggs, and a urinary hole [3].

Red tilapia has its advantages compared to other cultivated fish. Namely, it can proliferate, is easy to breed, and is efficient for feeding. Besides, these fish can also tolerate changes in the aquatic environment. With these advantages, this fish is increasingly popular among cultivators. The need for tilapia fish seeds is increasing every year [4].

According to statistical data from the Ministry of Marine Affairs and Fisheries in 2010-2013, tilapia production has increased significantly. In 2010, it was 446,191 tons. In 2011 it increased to 567,078 tons. In 2012, it increased again to 695,063 tons, and in 2013 it still increased to 909,016 tons [5].

The UPT of Freshwater Aquaculture Fisheries (PBAT) of Pasuruan Regency is one of the superior seed supply units for fisheries in East Java. The superior commodity is tilapia fish seeds. All broodstock in this UPT has been certified by the Fisheries Service. Throughout the year, it can continuously produce fish seeds, especially tilapia. It is due to useful hatchery techniques and water quality management. The seeds produced are of high quality and have so far filled the market in Gresik, Surabaya, Sidoarjo, and Pasuruan.

Tilapia hatchery techniques are usually done naturally. Naturally, these fish can spawn all year round in the tropics. The highest spawning frequency occurs during the rainy season. On average, once a month, tilapia will breed. This fish reaches the adult stage, reaching 4-5 months, and weighs about 250 grams. The productive spawning period is when the mother tilapia is $1.5-2$ years old. With a weight above 500 grams/head [6].

\section{Media preparation}

The hatchery site must have a technically adequate source of water and be available all year round. In spawning activities, a good water discharge for tilapia is only $1 \mathrm{~L} / \mathrm{s}$. If it is too heavy for tilapia to spawn, it is necessary to run water to replace the evaporation that occurs. The ideal tilapia spawning pond has concrete walls and soil basis, the shape of a pond based on soil is preferred by tilapia because it is inhabited by zooplankton and phytoplankton which are its natural food [7]. 
Carry out the hatchery, two types of ponds are needed: the spawning pond and the nursery pond. The spawning pond is made entirely of concrete, while the nursery pond is given a tarpaulin layer.

\section{Spawning Pond Preparation}

There are two types of spawning ponds, the first type is $2 \times 4$ meters, and the second is $4 \times 8$ meters. It is used for large ponds $(4 \times 8 \mathrm{~m})$ for sires that are still beginners to be spawned, while small pools $(2 \times 4 \mathrm{~m})$ are used for mature sires. Also, the pond's size is used according to the fish's capacity being spawned. The more fish that are spawned, the larger the pond is. All ponds for spawning are made of concrete with a depth of 1 meter. The total number of ponds available for spawning is 11 ponds, two small pools, and the large rest ponds.

Before spawning, the pool is prepared first by cleaning it from any remaining dirt or moss. Once clean, the pond is filled with water with a depth of $50 \mathrm{~cm}$. The water should be flow continuously to prevent silting due to evaporation. Clean water supports the results of red tilapia spawning. Therefore, water quality parameters also need to be considered.

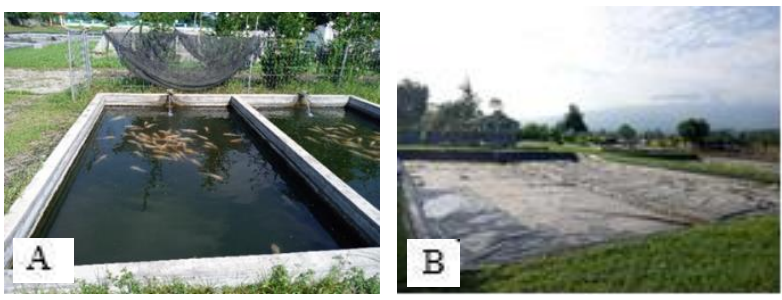

Figure 1. (A) Spawning Pond (B) Nursery Pond

\section{Nursery Pond Preparation}

The nursery pool has two ponds, each measuring $5 \mathrm{x}$ 10 meters with a depth of $70 \mathrm{~cm}$ made of concrete with a tarpaulin layer on the outside. Like spawning ponds, before being used for nursery tilapia larvae, the pond is first cleaned. In addition to cleaning dirt and moss, it is also to ensure that no pests or diseases are left in the pool. Therefore, after draining the pond, potassium is usually spread so that the pests die. It is safe to use for nursery tilapia larvae.

\section{Parent Selection}

To produce superior seeds in quality and quantity, it is very dependent on the broodstock [8]. Before being spawned, the male and female sires are separated (bent) for 10-14 days. It aims to ripen the parent hormones and sterilization, especially for female sires, to ensure that no eggs are stored in their mouths. Because the purpose of spawning here is mass spawning, so all brooders must ensure that the spawning time is the same. Besides, to minimize the uniformity of larvae/seed size produced. Non-uniform seed sizes interfere with the spawning process because large seeds will usually eat small ones.

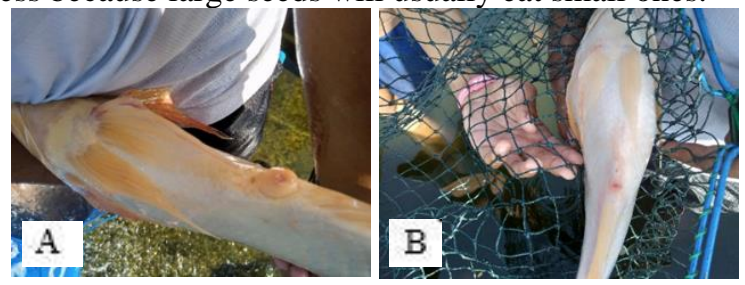

Figure 2. (A) Male and (B) female fish
The broodstock selected are those that have matured gonads by observing the physical condition of red tilapia. Physically, good broodstock is neatly arranged scales. Fish body parts are not deformed and injured. Standard body shape, agile movements, and male red tilapia's body color are brighter than female fish. The characteristics of mature female gonads are the genital shape near the anus that is round, protruding, and reddish. Male sires have tapered genital signs extending behind the anus and clear discharge when massaged around the genitals [3].

The broodstock's size also needs to be considered. To be spawned must use a uniform breed in one pond. There are two types of broodstocks size. The first is mature sires with a size of 2500-2700 gr, and the second is a starter breed with a size of 300-500 gr. For beginners, sires use a large pool because there are many (200 ind/pond). At the same time, there are mature sires in small ponds and the rest in large ponds.

\section{Spawning}

After selecting the broodstock, the next step is spawning. According to [8], the ideal ratio of male and female parents who are mated is usually $1: 3$, if the male parent is inserted into the pool as many as 15 heads, then 45 female parents must be provided. Naturally, fish usually spawn in the rainy season.

Spawning in UPT PBAT is done naturally with a male and female ratio of 1: 3 . Natural spawning is spawning, which is done by marrying male and female tilapia sires without hormone injections. There are two kinds of fish spawned weight as previously described. During the spawning process, control will be carried out every day to ensure pests' health and cleaning. Intensive control was carried out on days $18-21$ because usually, the fish larvae had started to come out.

In the process of spawning, tilapia broodstock requires feed with a recommended protein of $28-30 \%$ to meet its energy needs. Artificial feed (pellets) made from bran, soybeans, or beans. Pellets can be given $3-6 \%$ per day of parent weight [6].

Feeding during spawning decreases every day because the female sires have incubated the eggs/larvae in their mouths [9]. Feed that should be 800 grams will reduce to 500 grams in one feed. The feed given is artificial feed with the type of 782, which contains $29-31 \%$ protein, $4 \%$ fat, $5 \%$ fiber, $13 \%$ ash content, and $12 \%$ moisture content. In the afternoon, the feed will be reduced again because the fish appetite has decreased due to organic food, namely photosynthetic phytoplankton during the day.

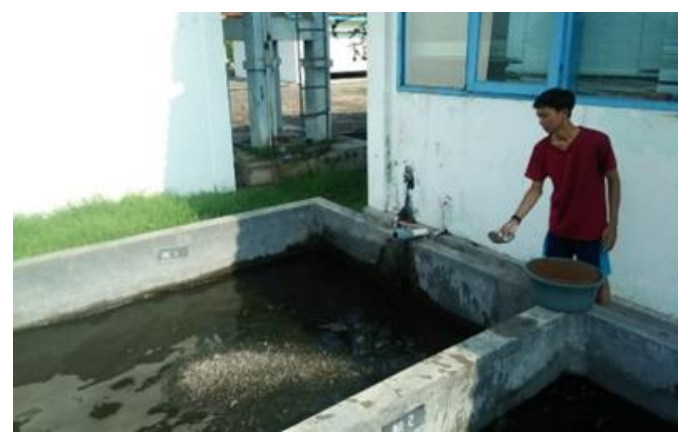

Figure 3. Simple fish pond 
The uniformity of size is critical so that the fertilization process runs smoothly. The uniform size is intended so that the fish do not attack each other. Also, to ensure sufficient oxygen levels for the growth and development of the resulting fish larvae. Water depth must also be considered. For spawning, the recommended depth is a range of 50 to $70 \mathrm{~cm} \mathrm{[6].}$

Female red tilapia usually incubates its eggs in the mouth for 10-13 days. Harvesting of fish larvae can be done on days 18-25 [6]. Harvesting time depends on the appearance of larvae that have been produced in the spawning pond. The season's influence also affects the time of harvesting. During the rainy season, the harvest time will usually be longer than the dry season. It cannot be separated from the sun's influence, which helps phytoplankton (natural food) photosynthesize. Rainwater intrusion also changes the composition of the waters, especially $\mathrm{pH}$ and DO.

\section{Larvae Harvest}

The harvest time was carried out on day 21 because many larvae had come out of the female fish's mouth. The harvest must be done at the right time. If it is too fast, the resulting larvae will be few, and many are still in egg form. Meanwhile, if it is too long, many of the larvae are eaten by male sires [1]. During the rainy season, the harvest time usually reaches the 25 th day, while the dry season is faster on the 18-21th day.

Harvesting larvae are carried out in the morning before harvest tilapia are not given food first. The necessary equipment is prepared in the harvesting technique, such as triangular net, broodstock net, water mop, and larvae\&broodstok basins. After that, while removing the water slowly, the larvae on the surface are taken slowly with a triangular net. It takes extra patience to harvest larvae because we have to be careful and careful not to die or get damaged. The drain pipe is replaced with a pipe with small holes while taking care to waste no larvae.

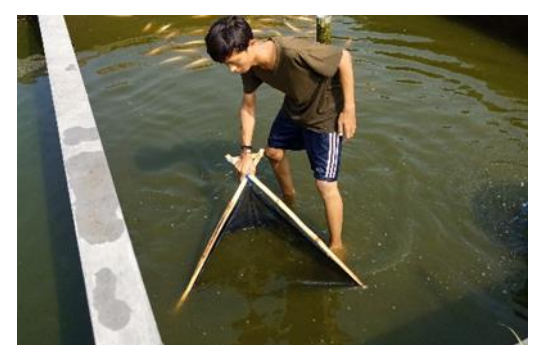

Figure 4. Larvae check and harvesting

While the water decreases, the larvae are also continuously taken with a triangle net until they run out. After that, the broodstock is taken with a batch of broodstock to be put in a blank. The male and female broodstock are separated into different belongs for a later turn. Try to fill the tub used for larvae because they need much oxygen to stay alive. Once full, the larvae are immediately taken to the handling area to be released on the incline. And so on until the larvae run out. Quality larvae will look agile and physically perfect (not defective).

\section{Larvae Treatment}

Treatment for larvae, larvae of red tilapia is put on a net in the handling area. The dirt that is picked up during the harvest is cleaned and removed by larvae net. The larvae are then left for 3-4 hours on the incline to flush out the existing dirt. Ensure the water flow is always flowing so that oxygen levels also increase because larvae are susceptible to oxygen needs. The water temperature must also be considered. If it is too hot, many larvae will die.

Next is the provision of MT (Methyl Testosterone). Based on [9], This chemical substance serves as a hormone to make fish males because, at the time of enlargement for fish consumption, male fish are used. The growth enhancement was more effective in masculinized fish.

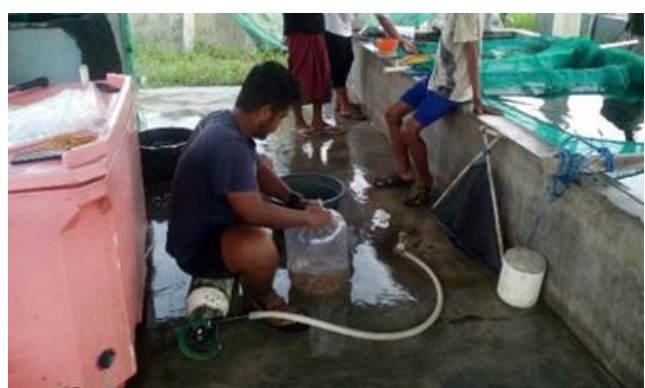

Figure 5. Larvae packed (after masculinization with MT)

The larvae were packed in a plastic bag and then given one tablespoon of MT. The duration of immersion with MT is approximately 8 hours. In one bag, the larvae number 15,000 . From the harvest results obtained three bags, meaning that the harvest this time got approximately 45,000 larvae. After 8 hours of immersion in MT, the larvae are ready to be transferred to the nursery pond.

\section{Nursery}

Nursery is the rearing of red tilapia from the hatchery before being released at the rearing place. The nursery for red tilapia is not much different from other fish. Nursery aims as a medium for adapting seeds to the environment before they are spread in an enlargement pond [4].

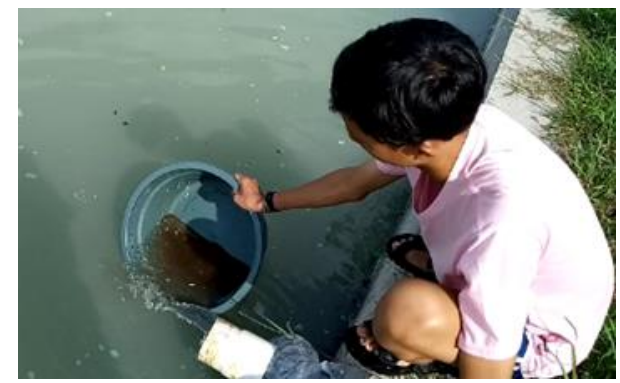

Figure 6. Larvae nursery

The nursery is carried out after the larvae are immersed in methyltestosterone. The larvae are released in the nursery pond that has been previously prepared. Care must be taken to release larvae so as not to damage the quality of the seeds. Release of larvae is recommended near waterways. When releasing fish, larvae get much oxygen and can immediately adapt to the nursery pond's conditions. The thing to note after the larvae are released is feeding. Feeding larvae as much as $3 \%$ of the total larvae weight, feed for larvae must also be mixed with water then made into fists like a ball. After that, it is spread out to be given to the red tilapia larvae. The nursery 
is carried out for ten days or more depending on the order of seed size requested.

\section{Harvest of Seeds}

After the nursery, the seeds will be harvested according to the size of market demand. The size of the seed yields varies according to the seedling stage. Stage I hatchery produces seeds $6-8 \mathrm{~cm}$ in size and weighs $8-10$ gr/ind. Stage II hatcheries produce seeds measuring 10-12 $\mathrm{cm}$ with a weight of 30-50 gr/ind and stage III producing seeds measuring 16-18 cm with a weight of $100 \mathrm{gr} / \mathrm{ind}$ [6].

After ten days or more of the seeds being harvested, the pond is first drained by replacing the drainpipe with a hollow pipe so that no seeds can escape. While waiting for low tide, the pond is cleaned using water mop so that when the seeds are taken, the water is clean. Like harvesting larvae, seeds are not given food for a while before harvesting. After the water recedes and is clean, the seeds will collect in the middle channel. Then the seeds are herded with a net to the water tap. After it is felt enough is collected, the seeds are taken with a seed and put in a tub filled with water. For seeds, it does not matter if the water in the tub is not too much. It also makes it easier for the transport process to handling because the fish cannot jump out of the tub.

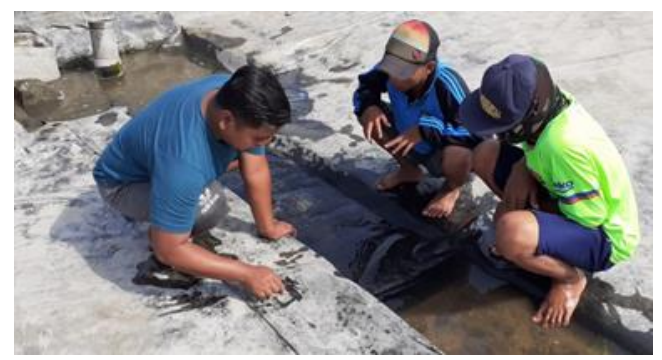

Figure 7. Harvest of seeds

The seeds are then taken to net in the handling area to be flushed, and the dirt is taken before being packed. This process takes about 5-6 hours to ensure the seeds' health to be ready for sowing. Furthermore, the seeds are packed with a special plastic to pack fish seeds. One bag usually contains 1.000-2.500 fish depending on size. The bigger the fish, the less fish in one bag. During the study, the seed harvest obtained many seeds even though not too many larvae were stocked. The larvae quantity that is stocked must also be considered if there are too many larvae that will die. Apart from fighting to overfeed, there is also a lack of dissolved oxygen in the pond.

\section{Water Quality Control}

Water quality is very influential on the process of red tilapia hatchery. Fish can survive normally and optimally if they are in good water quality. Water quality standards for biota are based on Indonesian government regulation (PP) no. 82 of 2001. pH range 6-9, DO more than $6 \mathrm{mg} / \mathrm{L}$, and temperature $25-30{ }^{\circ} \mathrm{C}[10]$.

In this study, samples of water quality control parameters were carried out in 4 ponds, two large ponds, and two small ponds. Observations were made for 21 days of spawning time. The number of broodstock spawned in each pond can be seen in Table 1 .
Ponds 1 and 2 relatively small which is used for mature sires, while in ponds 3 and 4 , the large one are brooders who are still beginners to be spawned. The total number of male sires was 130 heads and a total of 390 female brooders. Data were collected every day in the morning at 07.00 and 15.00 in the afternoon. The data taken are $\mathrm{pH}$, temperature, depth, and DO.

Table 1. The number of broodstock in the sample ponds

\begin{tabular}{|c|c|c|}
\hline Pond & Male (ind) & Female (ind) \\
\hline 1 & 15 & 45 \\
\hline 2 & 15 & 45 \\
\hline 3 & 50 & 150 \\
\hline 4 & 50 & 150 \\
\hline Total & $\mathbf{1 3 0}$ & $\mathbf{3 9 0}$ \\
\hline
\end{tabular}

Table 2. Result of water quality control

\begin{tabular}{|c|l|l|l|l|}
\hline Pond & Temperature $(\mathbf{C})$ & $\mathbf{D O}(\mathbf{m g} / \mathbf{L})$ & Depth$(\mathbf{m})$ & $\mathbf{p H}$ \\
\hline 1 & 28,4 & 7,6 & 0,5 & 8,3 \\
\hline 2 & 28,2 & 7,3 & 0,5 & 8,1 \\
\hline 3 & 29,6 & 8,1 & 0,5 & 8,4 \\
\hline 4 & 29,8 & 7,8 & 0,5 & 8,3 \\
\hline Average & 29 & 7,7 & 0,5 & 8,3 \\
\hline
\end{tabular}

The highest temperature was in pond 4 of $29,8 \mathrm{C}$, while the lowest was in pond 2 of 28,2 C. Sunlight dramatically affects the water temperature in the pond. The temperature is high in pool four because it is located in the middle without any sun barrier plants. While pool 2 has trees that slightly block the incoming sunlight.

The highest dissolved oxygen (DO) content was recorded at $8.1 \mathrm{mg} / \mathrm{L}$ in pond 3, while the lowest was 7.3 $\mathrm{mg} / \mathrm{L}$ in pond 2 . The effect of water circulation plays a significant role in the current DO levels. Also, the presence of phytoplankton affects oxygen content (DO). In pond 3, it looks transparent green, which indicates the amount of phytoplankton. In contrast, in pond 2, it is obvious indicating the lack of phytoplankton.

The degree of acidity $(\mathrm{pH})$ of the 4 sample ponds was the highest in pond 3 of 8.4 , while the lowest was in pond 2 of 8.1 . Nitrate and phosphate compounds significantly affect the $\mathrm{pH}$ scale. In aquaculture, nitrates and phosphates are associated with red tilapia feed and feces. The leftover feed will increase the nitrate and phosphate in these waters so that the $\mathrm{pH}$ will drop. It is what happened to pond 2, which has the lowest $\mathrm{pH}$. Overall, the water quality parameters, including temperature, $\mathrm{DO}, \mathrm{pH}$, and depth, are still good. They do not exceed the government's water quality standards through Indonesian Goverment Regulation (PP) no. 82 of 2001. Namely, pH range 6-9, DO more than $6 \mathrm{mg} / \mathrm{L}$, and temperature $25-30 \mathrm{C}$.

\section{Pest and Disease Control}

Every fish farming activity always has obstacles that can result in reduced cultivation productivity. The leading cause of this is the presence of pests and diseases. The pests that prey on tilapia are not much different from other freshwater fish pests. Some of the most common pests of tilapia that have deadly effects include Notonecta. This pest attacks fish seeds [5].

Diseases can cause fish stunted to growth, longer maintenance periods and high feed conversion. One of the diseases that often arise in tilapia is infection with the 
parasite Trichodina sp. This parasite attacks fish on the skin and gills. Trichodina $s p$. can penetrate into the lamellae gills and blood vessels, causing bleeding. The injuries caused can cause balance and respiratory disorders and even cause death [2].

At the time of the research, there were no pests and diseases. However, the factor causing the decline in the production of red tilapia seeds is a change in weather. During the rainy season, the water that comes from the rain will change the composition of the water quality in a controlled pond. Changes due to the addition of rainwater

\section{CONCLUSIONS}

Red tilapia could applied the natural spawning techniques with 1:3 male to female ratio. The spawning period is 21 days until harvest with two types of broodstock with mature sires $(2.500-2.700 \mathrm{gr})$ and novice

\section{REFERENCES}

[1] Santoso, B. 1996. Cultivation of Tilapia fish. Kanisius. Yogyakarta. pages 19-30.

[2] Amri, K., and Khairuman. 2007. Intensive Tilapia Cultivation. Agromedia Pustaka. Jakarta. pages 1621.

[3] Rukmana, R. 1997. Cultivation and Agribusiness Aspects. Kanisius. Yogyakarta.

[4] Djarijah, A.S. 1994. Intensive hatchery and rearing of red tilapia. Kanasius. Yogyakarta. pages 85-87.

[5] Kementrian Kelautan dan Perikanan. 2014. Extension of Tilapia (Oreochromis niloticus) Cultivation. Pusat Penyuluhan Kelautan dan Perikanan. Jakarta. pages 25-26.

[6] Suyanto, S. R. 2010. Tilapia hatchery and rearing. Cetakan Pertama. Penebar Swadaya. Jakarta. can lead to fish stress and increased fish mortality. The symptoms that occur are usually red tilapia. Their appetite will decrease, and the fish often cluster in the water faucet. Efforts to overcome this reduce the dosage of feed. There is no accumulation of leftover feed in the pond and controlling the water quality in the pond. Poor handling will result in stress and even death of the fish, which will affect the quantity and quality of seeds produced. Routine prevention efforts check the physical condition and behavior of fish in the pond every morning and evening.

sires (300-500gr). Water quality should be in quality standard by Indonesian goverment regulation (PP) no. 82 of 2001 with details of the average temperature of $29 \mathrm{C}$, DO 7,7 mg / L, pH 8,325, and water depth of $50 \mathrm{~cm}$.

[7] Sugiarto. 1988. Mujair and Tilapia Fish Hatchery Techniques. CV Simplex. Jakarta.

[8] Arie, U. 2007. Tilapia Fish Hatchery Techniques. Penebar Swadaya. Jakarta.

[9] Bustaman. (2007). The Effectiveness Of The 17 AMethyltestosterone Hormone To Manipulate The Gender Of Tilapia (Oreochromis niloticus) In The Maintenance Of Different Salinity. Indonesian Journal Of Marine Science and Technology, 1-7.

[10] Yulianti, P., T. Kadarini., Rusmaedi. dan S. Subandiyah. 2003. The Effect of Density on the Growth and Survival of Tilapia (Oreochromis niloticus) in Ponds. Jurnal Iktiologi Indonesia. Vol. 3 (2): 63-66. 